\title{
O VALOR DO ATO INCONSTITUCIONAL, EM FACE DO DIREITO POSITIVO BRASILEIRO
}

\author{
Manoel Gonçalves Ferreira Filho
}

I. Considerações preliminares - II. A doutrina tradicional - III. A inconstitucionalidade no direito brasileiro em vigor $-A)$ A omissão constitucional - B) As inovações da Lei $n^{\circ} 9.868$, de 10 de Novembro de $1999-$ a) A restrição de efeitos da inconstitucionalidade- $b$ ) $A$ inconstitucionalidade sem redução de texto - c) A interpretação conforme $-C$ ) Temperamentos à tese da nulidade - IV. Posições doutrinárias discordantes - a) A lição de Kelsen - b) A posição de Pontes de Miranda - V. Posicionamentos contemporâneos - a) Aspectos gerais - b) A graduação da desconstituição do ato inconstitucional - VI. Síntese conclusiva

\section{Considerações preliminares}

1. O tema e sua justificação

Não faz dúvida para a doutrina tradicionalmente aceita e ensinada no Brasil qual seja a natureza do ato inconstitucional. Tal doutrina brasileira consagra em sua esmagadora maioria - não seria exagerar muito, na sua unanimidade - a tese proveniente do Marbury v. Madison de que a norma inconstitucional é nula e írrita. A ela subscreve também a jurisprudência do Supremo Tribunal Federal.

Entretanto, parece-me necessário rediscutir essa tese, contrapondo-a ao direito positivo brasileiro, ao menos a partir da promulgação da Constituição de 1988, e sobretudo após as Leis $n^{\circ} 9.868$ e 9.882 , ambas de 1999 , uma que disciplinou a ação direta de inconstitucionalidade e a de constitucionalidade, outra, concernente à argüição de descumprimento de preceito fundamental.

Com efeito, é preciso ter presente a advertência de Kelsen:

R. Dir. Adm.,

Rio de Janeiro, 230: 217-236,

Out./Dez. 2002 
"A ciência do Direito não pode nem deve - nem direta nem indiretamente - criar o direito; deve limitar-se a conhecer o direito que criam os legisladores, os administradores e os juízes"!

\section{A constitucionalidade das inovações}

Põe-se aqui de parte a acesa discussão a propósito da constitucionalidade das inovações decorrentes das leis referidas.

Fato é que vigoram elas há três anos e não parece o Supremo Tribunal Federal apressado em decretar-lhes a invalidade ${ }^{2}$. Assim, até segunda ordem, devem ser consideradas como direito positivo no Brasil.

\section{Importância da questão}

A importância da matéria aqui tratada não precisa ser engrandecida. Concerne ela ao valor, ou desvalor, do ato inconstitucional e, portanto, ao próprio alcance e significação da supremacia da Constituição. Esta, em função da resposta, encontra a sua justa medida. Justa medida, aliás, que varia de ordenamento para ordenamento jurídico.

Quanto ao interesse prático do assunto, este é evidente, na medida que o contencioso de constitucionalidade é generalizado e diuturno após a vigência da Lei Magna de 1988.

Certamente, as dificuldades que o tema envolve são grandes. Resultam elas, desde logo, de inexistir uma doutrina consolidada a propósito da nulidade e da anulabilidade em direito público, ao contrário do que se passa com o direito privado.

\section{Plano do estudo}

O ponto de que se vai partir é a reprodução sintética da doutrina tradicional a respeito da desvalia do ato inconstitucional. Ou seja, a doutrina de Marshall tal qual recebida e interpretada no Brasil, seja na doutrina, seja na jurisprudência do Supremo Tribunal Federal.

Em seguida, proceder-se-á à análise do direito positivo brasileiro. Nisto, por um lado, serão examinadas as inovações da Constituição de 1988 e da legislação infra-constitucional posterior, por outro, se apontarão posições do Supremo Tribunal Federal, que discrepam da linha jurisprudencial preponderante.

Numa parte subsequiente, será confrontada a questão à doutrina kelseniana e a outros posicionamentos dissidentes em relação ao ensinamento tradicional.

A seguir, serão trazidos à colação opiniões doutrinárias mais recentes.

Enfim, numa última, à guisa de conclusão, será feito um inventário das lições colhidas.

1 Hans KELSEN, Prefácio, em Charles EISENMANN, La justice constitutionnelle et la Haute Cour constitutionnelle d'Autriche, Economica, Paris, 1986, p. VII.

2 E verdade que não as tem aplicado, talvez por falta de oportunidade. 


\section{A doutrina tradicional}

\section{A opinião de Marshall}

No pensamento jurídico brasileiro, a base da doutrina da inconstitucionalidade é a exposta por John Marshall, no caso Marbury v. Madison, julgado pela Suprema Corte, em 1803.

Ela está, essencialmente, no trecho seguinte ${ }^{3}$ :

"Ou a Constituição é a lei suprema, inalterável por meios ordinários, ou está no mesmo nível dos atos legislativos ordinários, e, como outros atos, é alterável quando agrade à legislatura. Se a primeira parte da alternativa é verdadeira, um ato legislativo, contrário à Constituição, não é lei (is not law); se a última parte é verdadeira, então as Constituições escritas são tentativas absurdas por parte do povo de limitar um poder, por sua própria natureza ilimitável."

De onde é retirada a conclusão:

"Um ato da legislatura, contrário (repugnant) à Constituição é írrito (void)".

\section{As implicações da tese}

A posição de Marshall fez, sem dúvida, escola nos Estados Unidos.

Cooley, Kent, Black, e todos os constitucionalistas que se tornaram conhecidos entre nós a partir das lições de Rui Barbosa, a subscreveram e difundiram ${ }^{4}$. O primeiro deles enunciou até a fórmula tantas vezes repetida:

"Lei inconstitucional é uma expressão enganosa (is a misnomer) e importa numa contradição. Tal ato não é, de fato, uma lei (in fact no law at all)"5.

E tal entendimento permeia a jurisprudência ${ }^{6}$.

Assim sendo, o tribunal, ao identificar a inconstitucionalidade de uma lei, simplesmente declararia a sua nulidade.

Em decorrência disto, seriam inválidos todos os efeitos do ato inconstitucional, já que este é nulo e irrito (null and void). Estes, na verdade, teriam de ser desconstituídos retroativamente (ex tunc).

3 Põe-se de lado, por não interessar ao tema deste estudo, a questão da competência do Judiciário para conhecer e apreciar a questão de inconstitucionalidade.

4 Cf. Zeno VELOSO, Controle jurisdicional de constitucionalidade, Del Rey, Belo Horizonte, 2000 , p. 177 e s.

5 Apud Lawrence Tribe, American Constitutional Law, Foundation Press, Mineola, 2*. Ed., 1988, p. 27.

6 Cf. Tribe, ob . cit, que exemplifica com o voto do Justice Field, no caso Norton v. Shelby County, p. 27. 


\section{Atenuações da posição}

É fato, porém - diga-se num parêntese - que mais recentemente a jurisprudência americana, e com ela a doutrina ${ }^{7}$, atenuaram esse posicionamento. A Corte Warren, por exemplo, nos anos cinquienta, adotou em várias decisões um posicionamento que ia além da mera declaração de inconstitucionalidade; assumia ademais um caráter prospectivo, indicando linhas positivas a serem seguidas para a realização em profundidade da Constituição, em particular para a garantia dos direitos fundamentais e para a luta contra a discriminação racial ${ }^{8}$.

Expressamente, a Suprema Corte rejeitou a tese do desfazimento ex tunc dos efeitos do ato inconstitucional. No caso Linkletter v. Walker (1965), é citada a afirmação do Justice Cardozo, de que "a Constituição nem proíbe nem reclama o efeito retroativo (retrospective effect)". E no caso Stovall v. Denno (1967) é dito que a questão da retroatividade ou da irretroatividade da desconstituição é uma opção de policy.

\section{A doutrina brasileira}

Ninguém ignora que Rui Barbosa difundiu no Brasil a doutrina de Marshall e seus seguidores. Muitos são os seus trabalhos em que está presente a tese da nulidade do ato inconstitucional. Um dos primeiros a fazê-lo - lembra Zeno Veloso ${ }^{10}$ contém a asserção:

"Toda medida legislativa, ou executiva, que desrespeitar preceitos constitucionais é, de sua essência, nula."

\section{As ilações}

Da mesma forma que a tese da nulidade, as ilações da doutrina norte-americana foram aqui consagradas. A esmagadora maioria dos juristas, não só afirma ser nulo o ato inconstitucional, como deverem ser desfeitos ex tunc os seus efeitos, logo que declarada a inconstitucionalidade. O tripé - nulidade, caráter declaratório da decisão, efeito ex tunc da desconstituição - são lugar comum nas obras nacionais, mesmo sem caráter didático ${ }^{\prime \prime}$.

\section{Alguns matizes}

Quanto à nulidade, raros são os que traem alguma dúvida, ou exprimem algum matiz, como Buzaid. Este aponta, sutilmente, que "a declaração de inconstituciona-

7 V. Tribe, ob. cit., p. 29 e s.

8 V., por exemplo, o caso Swann x Charlotte-Mecklenburg Board of Education. Cf. Ronald Dworkin, Levando os direitos a sério, trad. port., Martins Fontes, 2002, p. 206.

9 V. sobre essas duas decisões, Tribe, ob. cit, p. 30.

10 Ob. cit., p. 177, apontando para Os atos inconstitucionais do Congresso e do Executivo, Rio de Janeiro, Cia. Impressora, 1893, p. 47.

11 Nas obras didáticas, claro está que se tem de expor a doutrina generalizada, em particular quando ela é consagrada pelo Supremo Tribunal Federal. 
lidade importa nulidade da lei..., mas no sentido de lhe negar aplicação no caso concreto" 12 . Ou seja, vê nulidade, mas uma nulidade atípica.

Ou Lúcio Bittencourt que prefere falar em "ineficácia $a b$ initio da norma inconstitucional", ressalvando que esta ineficácia não poderia "ser entendida em termos absolutos"13.

Já Francisco Campos radicaliza a tese da ineficácia:

"Um ato ou uma lei inconstitucional é um ato ou uma lei inexistente; uma lei inconstitucional é lei apenas aparentemente, pois que, de fato ou na realidade, não o é. $O$ ato ou lei inconstitucional nenhum efeito produz, pois que inexiste de direito ou é para o Direito como se nunca houvesse existido." 14

E aduz:

“A expressão lei inconstitucional é uma "contradictio in adjecto"15.

Destoante, sem dúvida, foi Pontes de Miranda ${ }^{16}$.

\section{A jurisprudência do Supremo Tribunal Federal}

A jurisprudência dos tribunais brasileiros e a que importa, a do Supremo Tribunal Federal, não diverge da lição doutrinária.

É constante nos acórdãos desse Tribunal a tese de que o ato inconstitucional é nulo e írrito. Assim, tal inconstitucionalidade é meramente declarada e disto decorre apenas caber desfazer retroativamente os seus efeitos (ex tunc $)^{17}$.

Esta jurisprudência data da Primeira República, quando somente se admitia o controle de constitucionalidade difuso, concreto, em que as decisões somente possuem efeito inter partes. E continuou, após a reforma de 1965 que consagrou a ação direta de inconstitucionalidade, perdurando até hoje.

12 Alfredo BUZAID, Da açāo direta de declaração de inconstitucionalidade no direito brasileiro, Saraiva, São Paulo, 1958, p. 23. Claro está que ele raciocina a partir do controle difuso, em que a decisão somente alcança as partes, a menos que, mais tarde, venha o Senado a suspender a eficácia da norma. Mas ele o escreve num livro sobre a ação direta, o que faz suspeitar de que tal nulidade fosse atípica, se comparada com a registrada no direito privado.

13 C. A. Lúcio BITTENCOURT, O controle jurisdicional da constitucionalidade das leis, atualizado por José Aguiar Dias, Forense, Rio de Janeiro, 2. Ed., 1968, p. 148.

14 Francisco CAMPOS, Direito Constitucional, Freitas Bastos, Rio de Janeiro, vol. I, 1956, p. 430.

15 ld., ibid., p. 440.

16 V. infra $\mathrm{n}^{\circ}$

17 Cf., por todos, o acórdão na Rp. 971, rel. Djaci Falcão, RTJ 87/758. Muitas referências a tais acórdãos são encontradas em Gilmar Ferreira MENDES, Jurisdiçāo Constitucional, Saraiva, São Paulo, 1996, p. 253. 
12. A incoerência da aplicabilidade da norma já reconhecida como inconstitucional

A tese da nulidade do ato inconstitucional - observe-se de passagem - redunda numa incoerência em face do controle difuso. Dela só escapa o direito norte-americano em razão do stare decisis. Deste decorre, com efeito, que, uma vez declarada a inconstitucionalidade de uma lei, esta na realidade não mais se aplica.

No direito brasileiro, porém, inexiste esse instituto. Por isso, a decisão, em que é reconhecida a inconstitucionalidade, não colhe senão as partes litigantes. Disto resulta ser perfeitamente possível e admissível que uma norma nula ipso jure continue a ser aplicada. E somente em juízo, numa demanda, é que pode vir a ser reconhecida sua invalidade noutros casos.

Uma solução, aproximativa embora, veio com a Constituição de 1934, a qual previu caber ao Senado decretar a suspensão da execução de norma declarada inconstitucional em decisão definitiva do Supremo Tribunal Federal. Tal medida atenuou, embora não tenha resolvido o problema.

De fato, por primeiro, surgiu a dúvida: o Senado poderia ou deveria suspender tal norma?

A isto a doutrina, por larga maioria, respondeu que estaria essa Câmara adstrita a fazê-lo, apenas verificando os aspectos formais da declaração. Mas a prática do Senado não a seguiu, pois são numerosos os casos em que este simplesmente não decretou a suspensão, deixando as coisas ficarem como estavam.

Isto, entretanto, não respondeu à indagação óbvia: Um ato nulo ipso jure precisa ter sua execução suspensa ? $^{18}$ (E trouxe uma nova: Qual a diferença entre tal suspensão e uma revogação?)

Nesta busca de coerência, que, em relação à inconstitucionalidade declarada no controle difuso, não veio até hoje a existir, foi obtida quanto à inconstitucionalidade reconhecida no controle abstrato. Deveu-se isto a decisão que tomou o Supremo Tribunal Federal, em 1974, ao aprovar parecer do Min. Rodrigues de Alckmin, segundo o qual tais decisões tinham efeito erga omnes, não exigindo, portanto, a manifestação extensiva do Senado. E isto foi confirmado em 1977, em parecer do Min. Moreira Alves, adotado em resposta a consulta do próprio Senado Federal ${ }^{19}$.

\section{A inconstitucionalidade no direito brasileiro em vigor}

13. O controle de constitucionalidade sob a Constituição vigente

É fato conhecido que a Constituição em vigor, embora haja mantido o controle difuso, concreto, de constitucionalidade, deu ênfase ao controle concentrado, abstrato. No texto promulgado em 1988 , não só alargou a legitimidade para a ação direta

18 O que deu ensejo a uma ironia de Pontes de Miranda: "Leis inexistentes, essas, não precisam de suspensão." (Comentários à Constituição de 1946, Borsoi, Rio de Janeiro, 3' ed., tomo III, p. 463).

19 V. Gilmar Mendes, ob. cit., p. $251 / 2$. 
de declaração de inconstitucionalidade, como também previu a ação de inconstitucionalidade por omissão. E, pouco mais tarde, a Emenda Constitucional $n^{\circ} 3 / 93$, previu a ação de declaração de constitucionalidade. Em todos esses casos, é o controle abstrato que tem lugar.

Uma década depois, também como já se assinalou, a Lei n ${ }^{\circ} 9.868 / 99$, ao regular o processo e o julgamento da ação direta de declaração de inconstitucionalidade e a de declaração de constitucionalidade, referentes a atos normativos federais e estaduais, introduziu inovações de peso no sistema, que repetiu a Lei ${ }^{\circ} 9.882 / 99$, destinada a reger a argüição de descumprimento de preceito fundamental decorrente da Constituição, a qual, numa certa medida, consiste noutro meio de colocar em tese a discussão da constitucionalidade de ato normativo, admitindo o controle da adequação de ato normativo municipal em face da Carta Magna nacional, perante o Supremo Tribunal Federal.

Ora, cabe perguntar se essas inovações se coadunam com a doutrina tradicional.

\section{A) A omissão constitucional}

\section{A omissão como inconstitucionalidade}

A doutrina tradicional não conhecia como inconstitucionalidade senão a violação de norma constitucional exequível por si mesmo (self executing). Desobedecer a seu mandamento é que importava em inconstitucionalidade, inconstitucionalidade essa que deveria ser declarada pelos tribunais e, em suma, pelo guardião da Constituição, o Supremo Tribunal Federal.

Tal doutrina tradicional não se preocupava com o descumprimento de norma não auto-executável da Constituição. Certamente não via nisto uma inconstitucionalidade, na medida que falta eficácia a tais normas, pois esta, por uma opção do constituinte, foi condicionada à decisão política - de oportunidade e conveniência - de outro Poder, o Legislativo.

Ademais, ela admitia implicitamente faltar imperatividade às normas programáticas.

Contra isto, insurgiu-se, inspirada na jurisprudência alemã e na Constituição portuguesa de 1976, a Lei Magna de 1988. Desta decorre, com efeito, ser inconstitucionalidade o descumprimento da Constituição consistente em não tornar eficazes as normas programáticas, complementando-as e regulamentando-as.

\section{A ação de inconstitucionalidade por omissão}

O reconhecimento da omissão como inconstitucionalidade resulta da previsão, no texto de 1988, de uma ação de inconstitucionalidade por omissão (art. 103, $\S 2^{\circ}$ ).

Está no $\S 2^{\circ}$ do art. 102 da Carta vigente:

“ $\S 2^{\circ}$ - Declarada a inconstitucionalidade por omissão de medida para tornar efetiva norma constitucional, será dada ciência ao Poder competente para a adoção das providências necessárias e, em se tratando de órgão administrativo, para fazê-lo em trinta dias." 
Da simples leitura do texto decorre que a inconstitucionalidade por omissão não se coaduna com a sanção de nulidade. Nulidade do que não se fez?

Também não com o caráter declaratório da ação de inconstitucionalidade, pelo menos no caso da omissão de providência administrativa. Tem nesta hipótese evidente e insofismável caráter mandamental.

16. O mandado de injunção

E o mesmo resulta do mandado de injunção incompletamente enunciado no art. $5^{\circ}$, LXXI da Lei Magna:

"LXXI - conceder-se-á mandado de injunção sempre que a falta de norma regulamentadora torne inviável o exercício de direitos e liberdades constitucionais e das prerrogativas inerentes à nacionalidade, à soberania e à cidadania;"

Este, cujo caráter mandamental é flagrante, destina-se a suprir a falta de regulamentação de norma constitucional, portanto, importa numa violação por omissão de regras constitucionais concernentes ao exercício de direitos e liberdades constitucionais e das prerrogativas inerentes à nacionalidade, à soberania e à cidadania.

\section{Eficácia ex nunc}

Acrescente-se, enfim, que em todos estes casos a decisão reconhecedora da inconstitucionalidade tem obviamente eficácia ex nunc, não ex tunc, como era próprio da norma inconstitucional na doutrina clássica.

B) As inovações da Lei $n^{\circ}$ 9.868, de 10 de Novembro de 1999

\section{A Lei ${ }^{\circ} 9.868 / 99$}

A Lei $n^{\circ} 9.868$, de 10 de Novembro de 1999 , veio regular o processo e julgamento da ação direta de inconstitucionalidade e da ação declaratória de constitucionalidade perante o Supremo Tribunal Federal. Nela, inserem-se normas que merecem destaque pelo seu posicionamento em face da doutrina tradicional. É o que resulta do seu art. 27, complementado pelo art. 28 , disposições que são repetidas na Lei ${ }^{\circ}$ 9.882 , de 3 de dezembro desse mesmo ano, relativa à argüição de descumprimento de preceito fundamental nos arts. 11 e $10, \S 2^{\circ 20}$.

20 Já se lembrou haver contestação à constitucionalidade destas normas, inclusive posta perante o Supremo Tribunal Federal em ação declaratória de inconstitucionalidade. Não houve, todavia, a concessão de liminar, suspendendo qualquer delas. Na verdade, quando o STF não concede a suspensão liminar forte é a presunção (hominis) de que considerará constitucional a norma. Ora, como disse o Chief-Justice Charles Evans Hughes da Corte Suprema dos Estados Unidos da América — de modo realista e franco - "a Constituição é aquilo que a Corte Suprema diz ser"... 
19. $O$ art. 27 da Lei $n^{\circ} 9.868 / 99$

Atente-se para o texto do art. 27 da Lei $n^{\circ} 9.868 / 99$ :

"Ao declarar a inconstitucionalidade de lei ou ato normativo, e tendo em vista razões de segurança jurídica ou de excepcional interesse social, poderá o Supremo Tribunal Federal, por maioria de dois terços de seus membros, restringir os efeitos daquela declaração ou decidir que ela só tenha eficácia a partir de seu trânsito em julgado ou de outro momento que venha a ser fixado."

Do que se acaba de ler, decorre, em primeiro lugar, que o reconhecimento da inconstitucionalidade pode ter restringidos os seus efeitos. E pode tê-los restringidos, quer materialmente, quer temporalmente ${ }^{21}$.

\section{A restrição material}

A primeira, a restrição material, significa que o ato inconstitucional continuará, ao menos em parte, vigente e eficaz, produzindo os seus efeitos naturais (materiais). Ora, sendo lei, estabelecendo obrigações e limitações à liberdade, bem como autorizando ações do Estado, mesmo depois de reconhecida a inconstitucionalidade e sem prazo limite para tanto. O que é uma convalidação.

Em outros termos, pode ser reconhecido valor ao ato inconstitucional, valor de ato válido -- enfatize-se - a um ato inconstitucional. Disto não apenas resulta salvarem-se efeitos já produzidos pelo ato inconstitucional (que, portanto, não mais se desconstitui ex tunc), mas também lhe é conservada a aptidão a produzir efeitos para o futuro. A sua eficácia é conseqüentemente mantida. $O$ que importa na sua convalidação, o que exclui a nulidade da doutrina tradicional...

A conclusão inexorável é a de que o reconhecimento da inconstitucionalidade não implica a necessária nulificação do ato inconstitucional. Longo é o distanciamento em relação à doutrina tradicional, para a qual o ato inconstitucional era nulo e írrito.

Desta decorre outra conclusão de profunda importância para a supremacia da Constituição. Realmente, se um ato inconstitucional pode persistir vigente e eficaz mesmo depois de reconhecida a sua incompatibilidade com a Lei Magna, isto significa que ele prevalece sobre esta... Assim, fica ao menos abalada a rigidez da Constituição; é ela flexibilizada, eis que típico é das constituições flexíveis serem elas alteradas por lei infraconstitucional que as contradiz....

\section{A restrição temporal}

A restrição temporal decorre da possibilidade de ser fixado o momento a partir do qual o ato inconstitucional deixa de produzir efeitos válidos. Este momento pode 
ser estabelecido como o do trânsito em julgado da decisão, "ou de outro momento que venha a ser fixado" por esta. Quer dizer, no passado ou no futuro.

Quebra-se claramente um dos princípios da doutrina clássica, o dos efeitos ex tunc da desconstituição. E. se o momento de incidência da decisão for postergado para o futuro. continuará o ato inconstitucional a produzir efeitos como se válido fosse.

\section{A motivação da restrição}

É certo que o art. 27 citado subordina a restrição dos efeitos da "declaração" de inconstitucionalidade a "razões de segurança jurídica ou de excepcional interesse social".

Tais conceitos. porém, são extremamente amplos. Cobrem, na verdade. o que se quiser com eles cobrir. O primeiro, se tem uma caracterização relativamente determinada. pois, se pode dizer que "segurança jurídica" seria a manutenção de direitos gerados pelo ato inconstitucional, não exclui que o tribunal escolha entre os direitos que preserva e os que não preserva. Já o "interesse social" abrange tudo, ou ao menos tudo o que concerne à sociedade, o que não é pouco. Ademais, o que é de "excepcional" interesse social, cai no plano das apreciações subjetivas, personalíssimas.

Assim. o texto apenas finge apontar parâmetros para a restrição. No fundo, deixa-os à opinião da maioria exigida.

\section{A politização do controle de constitucionalidade}

Insista-se. Isto mostra que o controle de constitucionalidade assumiu um caráter político e que nele se pretende que o Supremo Tribunal Federal atue como órgão político.

Senão, veja-se.

A atribuição de eficácia ex nunc ou a partir de um determinado momento à decisão que reconhece a inconstitucionalidade pressupõe duas condições: uma. formal, ser tomada pelo quorum de dois terços dos Ministros do Supremo Tribunal Federal: outra, material. ocorrerem "razões de segurança ou de excepcional interesse social".

Esta derradeira é incontestavelmente uma apreciação de conveniência e oportunidade - de mérito, no sentido administrativo do termo. É uma apreciação tipicamente política. E subjetiva, porque admitir que haja razões de segurança, ou de interesse social, ainda mais quando qualificado de excepcional, depende da visão que cada um tenha das coisas.

Que se trata de uma apreciação política é tese reforçada pela exigência de quorum para tanto. Está nisto - é certo - uma cautela, visa a evitar que maioria exígua imponha sua visão da segurança ou do interesse social. Mas esta cautela adverte que a identificação desses fatores, por ser de fundo político, exige um certo consensus demonstrado pela maioria qualificada. Na verdade — insista-se no ponto - a maioria absoluta basta para decretar a inconstitucionalidade, mas não é suficiente para dosar os seus efeitos... 
Disto tudo decorre, em suma, a conclusão de que o Supremo Tribunal se torna (ou tende a se tornar) uma terceira Câmara do Poder Legislativo. De fato, ao convalidar um ato inconstitucional - pois é convalidar mantê-lo eficaz - ele "legisla"...

\section{4. $\mathrm{O}$ art. 28}

Reforça este entendimento o disposto no art. 28, caput, que manda publicar no Diário Oficial a parte dispositiva da decisão:

"Dentro do prazo de dez dias após o trânsito em julgado da decisão, o Supremo Tribunal Federal fará publicar em seção especial do Diário da Justiça e do Diário Oficial da União a parte dispositiva do acórdão."

Não terá sido o legislador traído pelo inconsciente? Não estará aí prevendo um ato análogo à publicação da lei? Que outro ato do Judiciário reclama uma publicação com todo formalismo exigido no texto, em "seção especial" não só do Diário da Justiça mas também do Diário Oficial da União?

\section{O efeito vinculante}

A importância desta publicação está em que ela transmite aos órgãos do Judiciário e da Administração a decisão restritiva. Ela condiciona o efeito vinculante e da eficácia contra todos da decisão. Isto decorre do parágrafo único do art. 28 :

"A declaração de constitucionalidade ou de inconstitucionalidade, inclusive a interpretação conforme $\mathrm{a}^{22}$ Constituição e a declaração parcial de inconstitucionalidade sem redução de texto, têm eficácia contra iodos e efeito vinculante em relação aos órgãos do Poder Judiciário e à Administração Pública federal, estadual e municipal."

E efeito vinculante não equivale, em termos concretos, a força de lei? Ele não obriga que se faça ou se deixe de fazer o que decorre da decisão judicial, tanto quanto resulta em geral da lei?

\section{Natureza constitutiva da decisão}

Último ponto a glosar. e insofismável, não se pode mais considerar declaratória a natureza da ação direta de inconstitucionalidade, mas sim constitutiva-negativa, para empregar a lição de Pontes de Miranda. Sim, porque a decisão não irá apenas declarar um fato - estar a lei viciada de inconstitucionalidade - mas irá desconstituí-la, neste ou naqueles termos, a partir deste ou daquele momento.

Disto resulta um problema. É compatível essa formulação com uma ação "declaratória" de constitucionalidade? Não se olvide que a ação de inconstitucionalidade é expressamente designada como declaratória (Constituição, art. 101, I, "a").

22 No texto oficial, publicado no D.O.U., inexiste crase. 


\section{Reconhecimento legal}

$\mathrm{O}$ art. 28, parágrafo único da Lei $\mathrm{n}^{\circ} 9.868 / 99$, confere status à inconstitucionalidade sem redução de texto de que o Supremo Tribunal Federal já usara ${ }^{23}$. Mas lhe atribui um plus, o efeito vinculante ${ }^{24}$.

Esta igualmente não se coaduna com a doutrina tradicional. Ela não importa na nulidade da norma, mas sim na sua mera ineficácia, num determinado quadro.

\section{c) A interpretação conforme}

\section{Reconhecimento legal}

Também está no referido art. 28, parágrafo único, a interpretação conforme à Constituição. Isto já o fizera no passado o Supremo Tribunal Federal, sem ter precisado de autorização legal ${ }^{25}$. Dá-lhe o texto - aqui também - o efeito vinculante.

Da mesma forma que na inconstitucionalidade sem redução de texto, aqui inexiste nulidade, ou nulificação.

Observe-se que, neste ponto, transparece um papel de "legislador" conferido ao Supremo Tribunal Federal. Realmente, a interpretação obrigatória que ele fixa se iguala a uma lei interpretativa. Esta fixa o sentido de norma a ela anterior, sentido este obrigatório.

\section{C) Temperamentos à tese da nulidade}

\section{As exceções à regra}

Cumpre registrar, ademais, que, se o Supremo Tribunal Federal subscreveu a tese da nulidade ipso jure do ato inconstitucional, nem por isso deixou de, em decisões específicas, introduzir atenuações no rigor do princípio. É o que assinala, com numerosos exemplos, Gilmar Ferreira Mendes que, como ninguém, conhece a jurisprudência do Supremo Tribunal Federal em matéria de controle de constitucionalidade. Fê-lo, seja por razões de segurança jurídica, seja ao admitir a inconstitucionalidade sem decretar a redução do texto $\operatorname{et}^{26}$. E certamente não faltam decisões em que a inconstitucionalidade foi tolerada como mera irregularidade ${ }^{27}$.

23 Cf. Gilmar Ferreira Mendes, Jurisdição constitucional, ob. cit., passim. Por exemplo, p. 261, p. 265 , etc.

24 Que na letra da Constituição somente é dado à decisão na ação de constitucionalidade.

25 Id., ibid.

26 Ob. cit., passim. Por exemplo. p. 261, p. 265, etc.

27 Não será o caso, recentíssimo. da constitucionalidade da prorrogação da CPMF, com dispensa do prazo exigido pela Constituição para a cobrança de contribuições? 


\section{A convalidação do ato inconstitucional}

E, mais, ao menos uma das súmulas do Supremo Tribunal Federal - a de $n^{\circ} 5$ - admite a convalidação de ato inconstitucional ${ }^{28}$. Diz ela:

"A sanção do projeto supre a falta de iniciativa do Executivo."

Que significa isto?

Como se sabe, a Constituição reserva em favor do Executivo a iniciativa legislativa quanto a determinadas matérias (como o faz o art. $61, \S 1^{\circ} \mathrm{da}$ Carta em vigor). A "falta de iniciativa do Executivo" quer dizer, de modo velado, a usurpação de iniciativa reservada ao Executivo por parlamentar, deputado ou senador. Tal usurpação configura evidente ato inconstitucional, que, segundo a doutrina tradicional tantas vezes repetida, importa em nulidade e ausência completa de efeitos válidos.

Mas nulidade - como sempre se entendeu - implica impossibilidade de convalidação, ao contrário do que resulta da Súmula.

Donde decorre que para o Supremo Tribunal Federal o ato inconstitucional é nulo, ma non troppo...

\section{Posições doutrinárias discordantes}

\section{A necessidade de uma revisão doutrinária}

Os dados acima reunidos, que não se ajustam à doutrina tradicional, justificam se recorra a outras lições dissidentes em relação à doutrina tradicional. Dentre elas, vale lembrar a de Kelsen, dentre os estrangeiros, a de Pontes de Miranda, dentre os brasileiros.

\section{a) A lição de Kelsen}

\section{Nulidade e anulabilidade}

Deve-se a Kelsen o primeiro questionamento retumbante da doutrina tradicional. Fê-lo em vários escritos, dentre os quais na Teoria Pura do Direito.

Neles, o Mestre vienense aponta ser a norma inconstitucional ${ }^{29}$ uma norma "anulável", embora "anulável" retroativamente. Por isso, sua doutrina é geralmente designada por teoria da anulabilidade da norma inconstitucional.

28 "A sanção do projeto supre a falta de iniciativa do Executivo". Esta súmula tem uma história agitada. Editada com as primeiras súmulas, foi abandonada mais tarde, em 1974, sob a alegaçāo de que seria incompatível com a Constituição então vigente. Mas não faz muito foi de novo aplicada. 1988 (V. sobre isto meu Do processo legislativo, Saraiva, São Paulo, $5^{2}$ ed., 2002, nº 133 e 134 , p. 214 e s.

29 Vale lembrar que Kelsen entende que a expressão lei inconstitucional não pode ser tomada ao pé da letra. "O seu significado apenas pode ser o de que a lei em questão, de acordo com a Constituição, pode ser revogada não só pelo processo usual, quer dizer, por uma outra lei, segundo o princípio lex posterior derogat priori, mas também através de um processo especial, previsto pela 
Presume isto, porém, que seja apreendido o seu posicionamento quanto à nulidade e à anulabilidade. Ensina ele a este respeito:

“Dentro de uma ordem jurídica, não pode haver algo como a nulidade, uma norma pertencente a uma ordem jurídica não pode ser nula mas apenas anulável. Mas esta anulabilidade prevista pela ordem jurídica pode ter diferentes graus. Uma norma jurídica em regra somente é anulada com efeitos para o futuro, por forma que os efeitos já produzidos que deixa para trás permanecem intocados. Mas também pode ser anulada com efeito retroativo, por forma tal que os efeitos jurídicos que ela deixou atrás de si sejam destruídos. ${ }^{30 \%}$

Ora, a lei inconstitucional é. sim. uma lei anulável (nulificável, proporia eu. ou "revozivel", como quer o tradutor) por um processo especial. É. sim. uma norma anulável con efeito retroativo, e neste sentido nula, pois, " a nulidade é apenas o grau mais alto da anulabilidade" 31 .

Max tal "lei foi válida até a sua anulação. Ela não era nula desde o início" :

Quanto à natureza da decisão que nulifica a lei, fácil é intuir ser ela de caráter constitutivo ${ }^{33}$.

\section{O sistema "austríaco"}

Estas idéias encontraram acolhida nas disposições concernentes à Corte Constitucional prevista na Constituição austríaca de 1920. Desta se originou um modelo que Mauro Cappelletti denomina de "austríaco" ${ }^{34}$, matriz do sistema praticado hoje nos Estados europeus.

Vale contrapor, nos termos do Mestre italiano, os dois sistemas de controle:

“No primeiro - a lei inconstitucional, na medida que se considera contrária a uma norma superior, é considerada absolutamente nula (null and void), e, em consequiência, ineficaz, de modo que o juiz que exerce a faculdade de controle, não anula, mas simplesmente declara uma nulidade (preexistente) da lei inconstitucional.

No ordenamento austríaco, ao contrário, a Corte Constitucional não declara uma nulidade, mas anula, cassa (aufhebt) uma lei que até o momento

Constituição. Enquanto, porém, não for revogada, tem de ser considerada como válida; e, enquanto for válida, não pode ser inconstitucional" (Teoria pura do Direito, trad. port. do dr. João Baptista Machado, Armênio Amado Ed., Coimbra, 1962, vol. II, p. 149.)

30 Id., ibid., p. 159.

31 Id., ibid., p. 162.

32 Id., ibid., p. 159.

33 ld., ibid., 169/170.

34 El control judicial de la constitucionalidad de las leyes en el derecho comparado, México, Universidad Nacional Autônoma, 1966, p. 66. 
em que a sentença da Corte se publica. é válida e eficaz. não obstante a sua inconstitucionalidade" 35 .

E aduz:

"Além disto, o que é ainda mais digno de nota, a Corte Constitucional possui a faculdade discricionária de dispor que a anulação da lei opere somente a partir de uma data determinada posterior à publicação (Kundmachung) de sua resolução, desde que o difermento da eficácia constitutiva da própria sentença não seja superior a um ano. "ih

\section{A manifestação de Leitão de Abreu}

Vale registrar que. certa feita. em julgamento no Supremo Tribunal Federal, o Min. Leitão de Abreu fez conhecer a sua divergência relativamente à doutrina tradicional ${ }^{37}$.

Com apoio em Kelsen - cita a General Theory of Law' and State - assinala entender. por um lado, que a decisão que reconhece a inconstitucionalidade tem caráter constitutivo, não declaratório. Por outro, entende que o ato inconstitucional é anulável, sendo essa anulação de índole retroativa. Ou seja, como diz o Mestre austríaco, em texto que cita, suscetível de "uma anulação com força retroativa".

Tal posição, isolada, não teve qualquer reflexo na orientação da Corte ${ }^{38}$.

\section{b) A posição de Pontes de Miranda}

\section{A questão da desconstituição do ato inconstitucional}

Encarando do ângulo processual esse tema, Pontes de Miranda sustentou o caráter constitutivo (negativo, ou desconstitutivo) da decisão que reconhece a inconstitucionalidade. Rejeitou, por inteiro, o caráter declaratório de tal sentença.

A seu ver, a tese tradicional colocaria a inconstitucionalidade no plano da existência, mas, na verdade. ela se situaria no plano da invalidade. $\mathrm{O}$ ato jurídico aponta - deve ser situado em "três planos: o da existência, em que o fato jurídico, inclusive a regra jurídica como fato. é, ou não é; o da validade, em que o fato jurídico vale, ou não vale (= é nulo ou anulável); e o da eficácia, que é o da irradiação do fato jurídico. ${ }^{3 \% *}$

Ora, o ato inconstitucional entrou no mundo do ser, existe, embora invalidamente. Há de ser desconstituído - é passível de invalidação — poderá e até deverá sê-lo retroativamente, mas não pode ser considerado como se não tivesse existido.

\footnotetext{
35 ld., ibid.

36 ld., ibid.

37 RE n ${ }^{\circ} 79.343$, RTJ 82/792 (795).

38 Gilmar Mendes, ob. cit. p. 255.

39 Comentários à Constituição de 1946, Borsoi. Rio de Janeiro, $3^{\mathrm{a}}$ ed., tomo VI. 1960, p. 418. Cito-o nos Comentários de 1946, pois os posteriores apenas o copiam.
} 
como inexistente: "O nec ullus romano "não existe; o nulo do jurista contemporâneo existe, mas anormalmente existe: nulamente é."

Explicite-se. De suas lições, depreende-se que o ato inconstitucional seria um ato existente, mas inválido, que haveria de ser desconstituído (invalidado) até retroativamente. Somente poderia ser dito "nulo", se por "nulo" se entendesse inválido.

Sem dúvida, a lição de Pontes de Miranda se aproxima da de Kelsen, mas não faz ele referência ao Mestre austríaco. Nem parece ter sido uma das fontes de inspiração das inovações recentes que recebeu o direito pátrio.

\section{Posicionamentos contemporâneos}

a) Aspectos gerais

\section{A doutrina moderna}

Hoje, na Europa, predomina entre a doutrina uma posição senão kelseniana, ao menos derivada dessa lição. Isto certamente se inspira do fato, de que, embora o direito positivo consagre a nulidade do ato inconstitucional, tal nulidade é concebida como o grau máximo de anulação do ato inconstitucional e se coaduna com temperamentos e restrições à sua desconstituição ${ }^{40}$. É o que se apreende, por exemplo, da rica e importante doutrina portuguesa ${ }^{41}$.

Entretanto, essa revisão doutrinária também se manifesta no Brasil, do que é exemplo este trabalho, entre vários outros recém produzidos, como o de Sérgio Resende de Barros ${ }^{42}$.

\section{A síntese da posição atual}

Encontra-se em Canotilho uma síntese dessa posição contemporânea. Aponta ele que, na matéria em exame:

40 Extremamente informativo é a este propósito Gilmar Mendes, no livro citado, Jurisdição Constitucional, para a Alemanha, e. para toda a Europa, a obra, também já citada. de Zeno Veloso, Controle de Constitucionalidade.

41 Neste último caso, estão os estudos de Jorge Miranda. Contributo para uma teoria da inconstitucionalidade (sem editor), de 1968, que forma o cerne do vol. VI de seu monumental Manual de Direito Constitucional, volume este intitulado Inconstitucionalidade e garantia da Constituição (Coimbra Ed., Coimbra, 2001): de Marcelo Rebelo de Sousa, O valor jurídico do ato inconstitucional (sem editor), de 1988. aos quais se deve acrescentar, embora de plano mais amplo. o recente livro de Carlos Blanco de Morais, Justiça Constitucional (Coimbra Ed., Coimbra, tomo I) de 2002. De caráter sintético, mas profundo, mencionem-se as observaçōes de Canotilho, no Direito Constitucional e Teoria da Constituição ( $2^{\star}$ ed., Almedina, Coimbra, 1998).

42 "Simplificação do controle de constitucionalidade", em As vertentes do Direito Constitucional contemporâneo, coordenado por Ives Gandra da Silva Martins, América Jurídica, Rio de Janeiro, 2002, p. 593 e s. 
"Os tópicos orientadores resumem-se da seguinte forma: (1) inconstitucionalidade e nulidade não são conceitos idênticos; (2) a nulidade é um resultado da inconstitucionalidade, isto é corresponde a uma reacção de ordem jurídica contra a violação das normas constitucionais; (3) a nulidade não é uma conseqüência lógica e necessária da inconstitucionalidade, pois, tal como na doutrina civilística a ilicitude de um acto pode conduzir à nulidade ou anulabilidade, e na doutrina administrativa a ilegalidade é susceptível de ter como reacção desfavorável a nulidade ou anulabilidade. também a constitucionalidade é susceptível de várias sanções, diversamente configuradas pelo ordenamento jurídico."

\section{b) A graduação da desconstituição do ato inconstitucional}

\section{A lição de Jorge Miranda}

Jorge Miranda, a seu turno. consagra a idéia dessa graduação. Vincula-a à gravidade do vício que macula o ato. Admite, em consequêencia, que qualquer descumprimento de norma constitucional seja, sempre, causa de invalidade do ato. Mais ainda, aceita que a inobservância de certas prescrições formais menores não invalida $o$ ato.

O Mestre de Lisboa, seguido por muitos outros, distingue quatro tipos de atos desconformes à Constituição: o ato inexistente, o nulo, o anulável e o (meramente) irregular. Para tanto, leva em consideração a importância e evidência do vício, ao que associa a sua forma de desconstituição ${ }^{43}$.

O primeiro é aquele que, dada a evidência — teratológica — de seu descompasso com a Constituição, não chega sequer a existir no mundo jurídico. Por isso, "não produz nenhuns efeitos desde a origem. sem necessidade de declaração". No direito português, a própria Constituição aponta casos de inexistência, como o da falta de promulgação de uma lei, falta de referenda para os atos que o exigem etc.

O segundo abrange os atos que não produzem efeitos desde a origem, mas é necessário que haja uma declaração por parte do órgão fiscalizador da inconstitucionalidade.

O terceiro compreende atos que, por um lado, somente deixam de produzir efeitos depois da decisão do controlador da constitucionalidade, admitindo-se a "sanação do vício".

O último engloba atos cuja desconformidade é irrelevante, não prejudica a produção de efeitos.

\section{Um critério objetivo}

Admitido que o ato inconstitucional não seja sempre nulo ipso jure, mas sim um ato cuja desconstituição seja graduada, impõe-se para tanto encontrar critério ou critérios razoáveis e objetivos. Estes devem ser fixados na própria Constituição, ou 
ao menos em lei para-constitucional, como uma lei complementar, para que não fiquem à mercê das conveniências de momento.

Uma proposta que tenho formulado parte da distinção clássica entre inconstitucionalidade material e inconstitucionalidade formal.

\section{A inconstitucionalidade material}

Esta, a inconstitucionalidade material, por importar em colisão com disposição substantiva da Constituição tem, numa escala de gravidade, o ápice ${ }^{+4}$. Realmente, a gravidade do descumprimento de norma material da Constituição, o mais das vezes definidora de direito fundamental ou de suas garantias, tem sempre o caráter máximo. ou, ao menos. caráter mais importante do que as inconstitucionalidades formais. não raro apenas procedimentais.

Deve ela. em consequência. ser sempre sancionada com a nulidade, desconstituindo-se ex tunc os seus eventuais efeitos.

\section{A inconstitucionalidade formal}

Quanto a esta. cabe levar em conta a medida em que ela deturpa a expressão da vontade geral que enuncia o Estado. De fato, o ato inconstitucional é necessariamente um ato editado pelo Estado (em suas várias projeções), ou seja, um ato que exprime a sua vontade — um ato jurídico-público. no dizer de Carlos Blanco de Morais $^{45}$ - mas uma vontade formada inadequadamente. vista a questão do ângulo formal.

$\mathrm{O}$ descumprimento do parâmetro formal - a inconstitucionalidade formal apresenta-se em grau muito variado de gravidade. Tanto pode ser tal que torne inexistente um ato, por lhe faltar elemento inerente à manifestação de vontade do órgão público, num extremo, como "lei" não votada pelo Legislativo: ou, noutro, mera irregularidade de procedimento. Igualmente, pode, num caso intermediário. ter todos os elementos de manifestação da vontade estatal, mas algum deles haver sido obtido de modo que não se ajusta plenamente ao parâmetro, como é o caso da lei tributária que viola o princípio da anterioridade.

Neste ponto, a lição portuguesa, com a distinção de tipos de ato inconstitucional, merece aplauso. Em função da gravidade da violação, pode ser graduada a sanção do vício, prevendo-se ou a nulidade absoluta, para o caso de "inexistência" do ato, ou de vício gravíssimo (se não se quiser recorrer o tipo "ato inexistente"), com o desfazimento retroativo dos efeitos: ou a anulabilidade, com restrição de efeitos, para os casos intermediários, admitindo-se a sanabilidade ou convalidação; ou a validação, sem qualquer restrição no tocante a efeitos, se ocorrer mera irregularidade, ou seja, descumprimento sem maior importância de prescrições procedimentais.

44 Cabe até perguntar se não serão essas disposições os verdadeiros "preceitos fundamentais" decorrentes da Constituição, a que alude o art. 102, $\S 1^{\circ}$ da Lei Magna em vigor.

45 Ob. cit., p. 121. 
42. Uma sistematização atualizada

Cabe, a final, procurar resumidamente apontar as linhas mestras do sistema a que se submete, no direito positivo brasileiro, o ato inconstitucional.

Cumpre fazê-lo tendo consciência de que, no plano da ciência:

“É preciso representar o direito como um sistema lógico, como uma ordem orgânica; perceber em que ponto exato deste sistema, desta ordem, tomarão lugar e funcionarão as normas que eles editaram; conhecer as conexões recíprocas, suas mútuas repercussões e em particular a estrutura interna do sistema para cuja edificação trazem materiais" ${ }^{46}$.

43. A nulidade de princípio

Com base na análise acima feita. resulta patente que. no direito hrasileiro em vigor, o ato inconstitucional somente é nulo e írrito, em princípio. ou globalmente falando.

Certamente é ele nulo, em princípio, como decorre do próprio art. 27 da Lei $\mathrm{n}^{\mathrm{o}}$ $9.868 / 69$, a contrario sensu.

\section{Desfazimento ex tunc}

Disto decorre que o desfazimento ex tunc dos efeitos do ato inconstitucional somente ocorre em princípio. Realmente, pode ser restringido, excepcionalmente, o alcance da desconstituição, seja material, seja temporalmente.

\section{A anulabilidade eventual}

Ora, em face desta restringibilidade, o ato inconstitucional aparece como um ato anulável, que pode ser desconstituído ex tunc. E esta desconstituição ex tunc é o que Kelsen designava por nulidade.

46. Os critérios da restrição

É certo que os fundamentos - "segurança jurídica" e "excepcional interesse social" - que autorizam a restrição de efeitos, são criticáveis, porque vagos e indeterminados. Ensejam uma discricionariedade que chega, no fundo, ao arbítrio.

Ademais, o último dos critérios é nitidamente político, não jurídico.

47. Risco de politização.

A discricionariedade apontada e, mais, o aspecto nitidamente político do "excepcional interesse social", levam a temer-se que a restrição de efeitos seja guiada por aspectos não jurídicos - políticos, numa palavra. Ora, isto levará a uma indesejável politização do Supremo Tribunal Federal. 
Reflete este matiz político o quorum de $2 / 3$ dos membros do Supremo Tribunal Federal para a restrição, o que não atenua o defeito, antes o evidencia.

48. A omissão.

É sem dúvida difícil enquadrar a omissão em qualquer dos casos acima. Todavia, ela mais se aproxima do segundo, da anulabilidade, eis que, com relação a atos anuláveis, sempre se aceitou, como se aceita, a convalidação. Ora, o reconhecimento da omissão induz ou enseja o seu suprimento, quer dizer, o saneamento da situação.

49. Natureza da decisão.

Quanto à natureza da decisão que reconhece a inconstitucionalidade, há variedade de soluções, exatamente em razão da variedade de efeitos que, hoje, pode assumir essa constatação de inconstitucionalidade.

Pode a decisão ter natureza declaratória - quando reconhece uma inconstitucionalidade como nulidade; ou constitutiva - quando opera uma restrição nos efeitos da inconstitucionalidade; ou mandamental, no caso da inconstitucionalidade por omissão.

50. Prevalecimento da doutrina kelseniana.

É incontestável que os registros feitos levam à conclusão de que a doutrina tradicional foi posta de parte. Incompatível com ela são várias das novidades adotadas pela Constituição e pelo direito a esta posterior. A própria nulidade aparece como uma desconstituição, um anulamento, de caráter retroativo, mas restringível.

Ao quadro identificado muito mais se ajusta a doutrina kelseniana ${ }^{47}$.

47 Sem dúvida, objetar-se-á que esta prevalência da visão kelseniana decorre de uma inconstitucionalidade. Ou, mais precisamente, que a possibilidade de restrição de efeitos do reconhecimento de inconstitucionalidade, é ela própria inconstitucional.

Qual, porém, o parâmetro de tal inconstitucionalidade? A doutrina tradicional, a jurisprudência majoritária?

Estāo aí fortes argumentos, mas contra eles se pode argüir que o Supremo Tribunal Federal sempre excepcionou a regra da nulidade. Mais, que o entendimento em prol da nulidade vinha da ausência da determinação legal dos efeitos da inconstitucionalidade, o que agora passou a existir.

Assim, não há razōes de otimismo para o sucesso da impugnação da constitucionalidade das inovações estudadas. 